\title{
Addressing Biodiversity Conservation Methods with Fagus sylvatica Genetic Indicators
}

\author{
Giovanni Figliuolo \\ Dipartimento delle Culture Europee e del Mediterraneo: Architettura, Ambiente, Patrimoni culturali (DiCEM), \\ Università degli Studi della Basilicata, Matera, Italy \\ Email: giovanni.figliuolo@unibas.it
}

Received 24 February 2014; revised 23 March 2014; accepted 22 April 2014

Copyright (C) 2014 by author and Scientific Research Publishing Inc.

This work is licensed under the Creative Commons Attribution International License (CC BY). http://creativecommons.org/licenses/by/4.0/

c) (i) Open Access

\begin{abstract}
Species biological history revealed by genetic indicators can provide guidelines for long-term biodiversity conservation in Natura 2000 network. Fagus sylvatica is the keystone species which regulates in the Mediterranean Eco-Region ecosystem structure, function and composition. Six hundred fifty nine $F$. sylvatica individuals have been sampled across 20 sites of European interest in Southern Italy and analyzed at 5 microsatellite loci. For sites marked by both maximum heterozygosity (Ho) and minimum heterozygote deficit (Fis) (IT9210210, ITA070099, IT9210205 and IT9220075) it is suggested to avoid impacts by adopting very conservative measures. Promoting migration processes (pollen flow and seed flow) would be appropriate where it has been monitored low heterozygosity and high genetic disequilibrium. Margin effect due to dryness should be buffered with appropriate belts of thermophilus broad leaved tree species.
\end{abstract}

\section{Keywords}

Fagus sylvatica, Genetic Diversity, Indicator, Natura 2000

\section{Introduction}

Natural, semi-natural habitats and species of interest under the E.U. directives (Habitats and Birds) should be protected either in the European Special Areas of Conservation (SAC) or Special Protection Areas (SPA), both integrated in the living space of Natura 2000 network [1] [2].

The montane belt of the Mediterranean Eco-Region is targeted by several Natura 2000 "sites", each bearing woods dominated by Fagus sylvatica L. (European beech). Beech is the keystone long-living species which 
regulates ecosystem structure, function and composition [3] [4]. The favourable conservation status of each protected site is a pre-requisite to maintain the ecologic and economic benefits. Thus, the regional-based implementation of conservation measures, biodiversity monitoring and governance are mandatory [1].

$F$. sylvatica sub-population genetic integrity in terms of composition (allelic richness and effective population size), structure (genetic diversity and genealogical structure) and functions (fitness and gene flow) [5] is necessary to gain the whole set of associated ecosystem benefits (e.g. water capture, soil protection, flora and fauna conservation) [6]. Complex relationships among living organisms [7] are linked to the genetic integrity of the dominant species (F. sylvatica in this case study) [4]. Mature beech wood, assessed as number of effectives ( $\mathrm{Ne}$ ), guarantees sufficient environmental humidity, dead wood, efficient seed production and pollination, richness of invertebrates (e.g. insects), vertebrates (e.g. amphibians), focal likens, bryophytes and fungi, food and nesting opportunity for birds, focal flora and resilience to environmental change [4].

It is suggested that it would be prudent to protect, above all, the keystone long-living species ( $F$. sylvatica) because it plays its major role in shaping the optimal ecological context [8]. After protecting and preventing impacts on beech wood, planning different species-specific protection measures would be realistic and, probably, effective.

Species communities focal to beech woods, in the southern-most latitude, are isolated on the mountain slopes or on high plains. Population fragmentation and geographic isolation on the mountain peaks will increase in the future because of global warming. Trends forecast tree migration of about $500-600 \mathrm{~km}$ northward by an increase of $2^{\circ} \mathrm{C}-3^{\circ} \mathrm{C}$ as well as migration on mountain tops [9]-[11]. F. sylvatica shows an efficient pollen-flow (wind pollinated) and very limited seed dispersal [12].

In South Italy the genetic structure of the native F. sylvatica is linked to the glacial niches and appears finely regulated by both the post-glacial migration processes across the landscape and site-specific impacts [8].

Beech in situ conservation is necessary to maintain or increase the species fitness in the coming centuries. Heterozygosis which is linked to plant resilience and adaptation can be maintained by applying conservation biology methods [3] [13].

Pedologic substrate and ground flora are currently used to differentiate beech forests: at high altitude on clay soils the herbaceous indicator is Asyneuma trichocalicinum; on brown soil is Melica uniflora and Pulmonaria vallarsiae and, on acid humus are Luzula and Milium effusum [14]. Phytosociological patterns being strictly related to relatively short-term environmental changes and even more to the complex biological knowledge of the experts [15] can be hardly associated to F. sylvatica genetic diversity which is the outcome of evolution.

Thus, genetic indicators of the species biological history would be appropriate to safeguard in situ sub-populations of long-living species [16].

Genetic diversity distribution at a regional spatial scale can easily be assessed with microsatellite loci (nuclear and cytoplasmic). The interpretation of basic genetic indicators, such as allelic richness, heterozygosis and deviation from genetic equilibrium, can consistently improve conservation guidelines.

In this study, genetic diversity at five nuclear and two chloroplastic micro-satellite loci has been assessed in different $F$. sylvatica sub-populations targeting 20 areas of European interest (South Italy) with the goal to fix a hierarchically first level management criterion for homogeneous habitats.

\section{Material and Method}

\subsection{Sampling Design}

F. sylvatica has been sampled across 20 sites scattered over the mountains of the Lucanian Apennine, Cilento, including Etna, Vulture and Foresta Umbra (Table 1). Leaves or buds for DNA isolation were harvested from aged beech individuals sampled spaced of 150 - 200 linear meters to avoid the sampling of close relatives. The whole population is represented by 659 individuals and each sub-population average census size is No. $=34$. Each individual plant has been in field geo-referenced and for each site, soil type, exposition, altitude, site name, forest composition and structure were recorded.

\subsection{Molecular Analyses}

Total genomic DNA was purified using the Trans-Prep chemistry and ABI PRISM 6100 Nucleic-Acid prep Station (Applied Biosystems). DNA concentration and quality was assessed either by gel electrophoresis or spectrophotometer. Five microsatellite loci (three nuclear and two chloroplastic), were analyzed (Table 2). Three out of 5 nuclear microsatellites, (FS1-03, FS3-04 and FS4-46) are mapped markers located on chromosomes LG1-F, 
Table 1. Natura 2000 sites sampled to assess Fagus sylvatica genetic indicators.

\begin{tabular}{|c|c|c|}
\hline E.U. Code & Mount & Site-specific "Standard Data Forms" can be accessed on: \\
\hline IT9210210 & Vulture & http://natura2000.eea.europa.eu/natura2000/SDF.aspx?site=IT9210210 \\
\hline ITA070099 & Etna & http://natura2000.eea.europa.eu/natura2000/SDF.aspx?site=ITA070009 \\
\hline IT9210205 & Volturino (Raimondo) & http://natura2000.eea.europa.eu/Natura2000/SDF.aspx?site=IT9210205 \\
\hline IT9220075 & Lago Duglia C. T. & http://www.natura2000basilicata.it/it9220075-lago-duglia-casino-toscano-e-piana-di-s-francesco \\
\hline IT9210190 & Paratiello & http://natura2000.eea.europa.eu/Natura2000/SDF.aspx?site=IT9210190 \\
\hline IT8050030 & Gelbison & $\underline{\text { http://natura2000.eea.europa.eu/Natura2000/SDF.aspx?site=IT8050030 }}$ \\
\hline IT9210110 & Faggeta Moliterno & http://natura2000.eea.europa.eu/Natura2000/SDF.aspx?site=IT9210110 \\
\hline IT9210195 & Raparo & http://natura2000.eea.europa.eu/Natura2000/SDF.aspx?site=IT9210195 \\
\hline IT9210215 & Li Foi & http://natura2000.eea.europa.eu/Natura2000/SDF.aspx?site=IT9210215 \\
\hline IT8050046 & Cervati & http://natura2000.eea.europa.eu/Natura2000/SDF.aspx?site=IT8050046 \\
\hline IT9210200 & Sirino & http://natura2000.eea.europa.eu/Natura2000/SDF.aspx?site=IT9210200 \\
\hline IT9210240 & Serra Calvello & http://natura2000.eea.europa.eu/Natura2000/SDF.aspx?site=IT9210240 \\
\hline IT9210115 & Pierfaone & http://natura2000.eea.europa.eu/Natura2000/SDF.aspx?site=IT9210115 \\
\hline IT9210170 & Caldarosa & http://natura2000.eea.europa.eu/Natura2000/SDF.aspx?site=IT9210170 \\
\hline IT8050053 & Alburni & http://natura2000.eea.europa.eu/Natura2000/SDF.aspx?site=IT8050053 \\
\hline IT9210180 & Madonna Viggiano & http://natura2000.eea.europa.eu/Natura2000/SDF.aspx?site=IT9210180 \\
\hline IT8050034 & Maddalena & http://natura2000.eea.europa.eu/Natura2000/SDF.aspx?site=IT8050034 \\
\hline IT9210165 & Alpi & http://natura2000.eea.europa.eu/Natura2000/SDF.aspx?site=IT9210165 \\
\hline IT9210185 & La Spina & http://natura2000.eea.europa.eu/Natura2000/SDF.aspx?site=IT9210185 \\
\hline IT9110004 & Foresta Umbra & http://natura2000.eea.europa.eu/Natura2000/SDF.aspx?site=IT9110004 \\
\hline
\end{tabular}

Table 2. Fagus sylvatica microsatellite loci, amplification primers, allele types and reference.

\begin{tabular}{|c|c|c|c|c|}
\hline Locus & Primer 5’-3' & $\begin{array}{l}\text { Alleles MW range } \\
\text { (bp) }\end{array}$ & $\begin{array}{l}\text { Alleles } \\
\text { (No) }\end{array}$ & Ref. \\
\hline FS4-46 & GCAGTCCTCCACСATTACTATACAACAGCAGGCTATCCAT & $197-400$ & 14 & {$[18]$} \\
\hline FS1-03 & Ned-CACAGCTTGACACATTCCAACT GGTAAAGCACTTTTTCCCACT & $96-136$ & 22 & [18] \\
\hline FS115 & Vic-TCAAACCCAGTAAAATTTCTCAGC CTCAATGAACTCAAAAAC & $107-139$ & 18 & [18] \\
\hline FS3-04 & Fam-AGATGCACCACTTCAAATTCTCTCСТCAGCAACATACСTC & $209-220$ & 5 & [18] \\
\hline MFC5 & Fam-ACTGGGACAAAAAAACAAAAGAAGGACCAAGGCACATAAA & $281-386$ & 30 & [19] \\
\hline Cmcs3 & Fam-AGAGTAAGGTTTTATTAGTATAGACTCGATAGTATTTGTCGAT & $181-182-183$ & 3 & {$[20]$} \\
\hline Cmcs12 & Vic-ATATTGGTAAAACGGCAACTTTTATGGCATGAAAACAACTC & $246-247-248$ & 3 & {$[20]$} \\
\hline
\end{tabular}

LG3-M e LG11-M respectively [17]. To carry out capillary electrophoresis the forward microsatellite primer was labelled in 5' position with different dyes (6-Fam, Vic and Ned). At 5' end of the reverse primer a tail bearing the GTGTCTT sequence was added in order to reduce the plus-A effect. PCR reactions for nuclear loci were carried out in 25 ul, containing 20 - 30 ng of target DNA, buffer 1X (200 mM Tris- HCl, pH 8.4, 500 mM KCl), $2 \mathrm{mM}$ of MgCl2, $0.2 \mathrm{mM}$ of dNTPs (Invitrogen), $0.4 \mathrm{uM}$ of each primer (Applied Biosystem), $1 \mathrm{U}$ of Taq DNA polymerase (Invitrogen). Thermocycler was programmed as it follows: 5 minutes of DNA denaturation $\left(95^{\circ} \mathrm{C}\right.$, 30 cycles at 1 minute of DNA denaturation $\left(95^{\circ} \mathrm{C}\right), 1$ minute of annealing at $60^{\circ} \mathrm{C}, 1$ minute of extension $\left(72^{\circ} \mathrm{C}\right)$ with a final extension of 8 minutes $\left(72^{\circ} \mathrm{C}\right)$. The DNA at the two chloroplast loci (Cmcs3 and Cmcs12) was amplified with little modifications $\left(0.2 \mathrm{uM}\right.$ of each primer, 35 cycles, annealing temperatures at $52^{\circ} \mathrm{C}$ and a final extension for 5 minutes at $72^{\circ} \mathrm{C}$ ) of the original protocol [24]. Capillary electrophoresis has been achieved using the 3130 sequencer (Applied Biosystems) adopting the standard running conditions: 1 - 1.5 ul of PCR products were diluted in $10 \mathrm{ul}$ of formamide; DNA denaturation occurred at $95^{\circ} \mathrm{C}$ for $3-5$ minutes, cooled on ice for 5 10 minutes and than loaded on microplates before starting the run. With the software Gene-Mapper 3.7 (Applied 
Biosystems) each peak has been converted to molecular weight by applying the options microsatellite default full range and local Southern.

\subsection{Statistical Analyses}

Data analysis adopted a Bayesian approach [21]. Expected heterozygosity ( $\mathrm{He}$ ), observed heterozygosity (Ho), fixation index (Fis) and allelic richness (A) were computed using Genetic Data Analysis software [22]. Allelic richness has been also standardized using the rarefaction method [23]. The ranking of sub-populations by the increasing $F_{i s}$ allowed the identification of beech stands close to the Hardy-Weinberg equilibrium.

\section{Results}

The average number of alleles per locus is $A=9.7$ (Table 3). The number of nuclear alleles per site is evenly distributed while the chloroplast alleles are more localized. On average, the observed heterozygosis is lower than the expected $\left(H_{o}=0.56\right.$ vs $\left.H_{e}=0.78\right)$ and the heterozygote deficit measured by the fixation index is $F_{i s}=0.28$ (Table 3).

After ranking Natura 2000 sites by the increasing $F_{i s}$ it has been possible to identify three groups of sites. The first including beech stands close to the Hardy-Weinberg equilibrium (Vulture, Etna, Volturino, Lago Duglia with low fixation index); the second with intermediate fixation index (Paratiello, Gelbison, Moliterno, Raparo, Li Foy, Cervati, Sirino, S. Calvello, Pierfaone, Caldarosa) and the third group with high fixation index bearing sub-populations in strong disequilibrium (Alburni, M. Viggiano, Maddalena, Alpi, La Spina, Foresta Umbra). Overall, as expected, sites with higher observed heterozygosity revealed a lower fixation index and vice-versa ( $r$ $=-0.91 \mathrm{P}<0.05)($ Table 3 and Figure 1).

Chloroplastic markers detected height $F$. sylvatica haplotypes across the whole set of sites. The maximum of six different haplotypes is on Etna volcano; it follows Cervati (four haplotypes) and Vulture volcano (three haplotypes) (Table 3). The latter three sites, because of maternal marker richness are likely the most close to the pre-glacial beech locations (Table 3). Cervati should be the beech wood close to a glacial niche because of its richness of maternal haplotypes although as consequence of historical impacts the last old growth generation has a higher Fis. Sites with just one haplotype indicate recent colonization.

\section{Discussion}

Heterozygote deficit at microsatellite loci $\left(F_{i s}\right)$ is an indirect estimate of the deviation from equilibrium due to non-random mating. The average fixation index is higher $(F i s=0.28)$ than what reported using isozymes for the European assessed beech population (Fis $=0.115$ ) [24], or with microsatellites for the Italian $($ Fis $=0.117)$ [25], or European populations (Fis $=0.192)$ [26].

Several sub-populations (group two and three) with high heterozygote deficit affect the average Fis average value. High Fis values are generated by the pollination among close relatives very likely in sub-populations with low Ne (Figure 2), often reproductively isolated by distance (or phenology). Natural (e.g. valleys) and human generated (e.g. coppicing, clear-cutting and land use) ecological fragmentation has contributed to geographic isolation and, in parallel, to the reduction in sizes of the effective number of trees (data not shown). It is currently argued that, even if the demographic census size is high, a dense tree composition of each forest could perform as a sort of barrier for pollen migration. Nonetheless this hypothesis has never been validated with data. In addition, forest composition with different tree species (mixed woods) or pure stands with heterogeneous patterns can favour pollination efficiency. Etna, Vulture, Lago Duglia and Paratiello (high Ho and low Fis) have all beech stands irregularly patterned and often (Etna and Vulture) mixed with different perennial species (data not shown).

Etna and Vulture are challenging sites from the conservation point of view because, despite their geographic isolation and low demographic densities, they show high heterozygosity and genetic equilibrium.

From the analysis of the genetic indicators in this paper it is inferred that:

1) High allelic richness for chloroplast haplotypes demonstrates either proximity of the actual populations (Etna and Vulture) to the pre-glacial sites and/or appropriate $\mathrm{Ne}$.

2) Natural selection in these sites acted a pressure over a long time-scale (interglacial).

3) The actual phenotypes express highest fitness to present and future ecological conditions. 
Table 3. Genetic diversity of Fagus sylvatica sub-populations measured with the following indicators: Ho, He, Fis, A and chloroplast haplotype number. Sites are sorted by Fis.

\begin{tabular}{|c|c|c|c|c|c|c|c|c|c|c|c|}
\hline 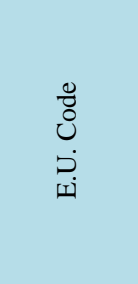 & 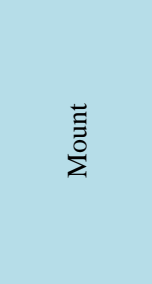 & 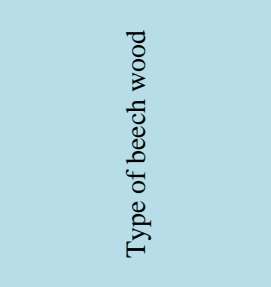 & 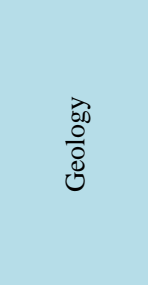 & 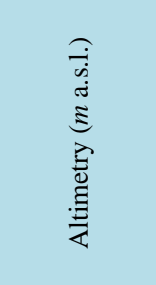 & 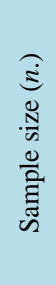 & 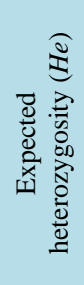 & 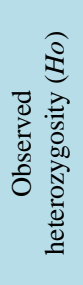 & 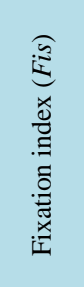 & 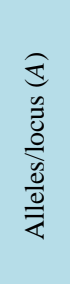 & 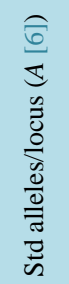 & 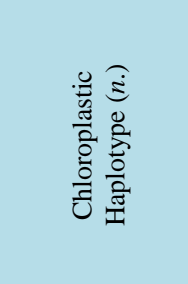 \\
\hline IT9210210 & Vulture & $\begin{array}{l}\text { Mixed with } Q \text {. } \\
\text { cerris > 10\%; Abies } \\
\text { present }\end{array}$ & Volcanic & $590-1100$ & 16 & 0.727 & 0.675 & 0.072 & 7.8 & 3.01 & $\begin{array}{c}\mathrm{H} 1(12) ; \mathrm{H} 2(3) ; \\
\mathrm{H} 4(1)\end{array}$ \\
\hline ITA070099 & Etna & $\begin{array}{l}\text { Mixed with Castanea } \\
\text { sativa, Pinus nigra } \\
\text { and Genista aetnensis }\end{array}$ & Volcanic & $>1500$ & 11 & 0.747 & 0.675 & 0.096 & 5.4 & 2.94 & $\begin{array}{l}\text { H2(1); H3(2); } \\
\text { H6(4); H7(2); } \\
\text { H8(2) }\end{array}$ \\
\hline IT9210205 & $\begin{array}{l}\text { Volturino } \\
\text { (Raimondo) }\end{array}$ & $\begin{array}{l}\text { Dominant with } \\
\text { termophile shrubs } \\
\text { present and rare } \\
\text { Acer spp. }\end{array}$ & $\begin{array}{l}\text { Siliceous- } \\
\text { carbonate }\end{array}$ & $1046-1290$ & 18 & 0.803 & 0.700 & 0.128 & 9.6 & 3.11 & H1(18) \\
\hline IT9220075 & $\begin{array}{c}\text { Lago Duglia } \\
\text { C. T. }\end{array}$ & Abies alba $<10 \%$ & $\begin{array}{l}\text { Carbonate- } \\
\text { siliceus }\end{array}$ & $1070-1680$ & 18 & 0.788 & 0.673 & 0.147 & 9.8 & 3.20 & Н3(18) \\
\hline IT9210190 & Paratiello; & $\begin{array}{c}\text { Mixed with } Q \text {. } \\
\text { cerris }<10 \%\end{array}$ & Carbonate & $890-1250$ & 46 & 0.807 & 0.630 & 0.219 & 10.4 & 3.40 & H1(23); H2(24) \\
\hline IT8050030 & Gelbison; & $\begin{array}{l}\text { Dominant with several } \\
\text { broadleaf spp. }\end{array}$ & $\begin{array}{l}\text { Arenaceus- } \\
\text { carbonate }\end{array}$ & 1250-1693 & 16 & 0.785 & 0.525 & 0.223 & 8.4 & 3.38 & H2(13); H4(3) \\
\hline IT9210110 & $\begin{array}{l}\text { Faggeta } \\
\text { Moliterno }\end{array}$ & $\begin{array}{c}\text { Dominant with } \\
\text { presence of Ilex } \\
\text { aquifolium, Corylus } \\
\text { avellanae, Carpinus } \\
\text { spp and Cornus mas }\end{array}$ & Carbonate & $>900$ & 25 & 0.751 & 0.56 & 0.254 & 8.8 & 3.03 & H2(2); H4(23) \\
\hline IT9210195 & Raparo & Pure stand & Carbonate & $1320-1600$ & 18 & 0.767 & 0.567 & 0.261 & 8.2 & 3.11 & H2(18) \\
\hline IT9210215 & Li Foi & $\begin{array}{c}\text { Pure stands + patches } \\
\text { of } Q \text {. cerris and } I . \\
\text { aquifolium }\end{array}$ & $\begin{array}{l}\text { Carbonate- } \\
\text { siliceus }\end{array}$ & $1055-1314$ & 44 & 0.805 & 0.593 & 0.263 & 10.6 & 3.33 & H2(44) \\
\hline IT8050046 & Cervati & $\begin{array}{c}\text { Dominant with Acer } \\
\text { spp. plus } C \text {. sativa }\end{array}$ & Carbonate & $1335-1795$ & 46 & 0.782 & 0.574 & 0.266 & 11.4 & 3.18 & $\begin{array}{l}\text { H1(5); H2(1); } \\
\text { H3(7); H5(33) }\end{array}$ \\
\hline IT9210200 & Sirino & Pure stand & Carbonate & $1279-1650$ & 11 & 0.697 & 0.509 & 0.270 & 4.8 & 2.59 & H2(11) \\
\hline IT9210240 & $\begin{array}{c}\text { Serra } \\
\text { Calvello }\end{array}$ & $\begin{array}{c}\text { Dominant with } Q \text {. } \\
\text { cerris < } 10 \% \text {; A. alba } \\
\text { present. }\end{array}$ & Carbonate & $1159-1390$ & 114 & 0.795 & 0.578 & 0.273 & 13.2 & 3.20 & H1(114) \\
\hline IT9210115 & Pierfaone & $\begin{array}{l}\text { Dominant with } Q \text {. } \\
\text { cerris }<10 \% \text {; } \\
\text { A. alba present. }\end{array}$ & $\begin{array}{l}\text { Carbonate- } \\
\text { siliceus }\end{array}$ & $1288-1570$ & 60 & 0.783 & 0.565 & 0.278 & 11.2 & 3.21 & H1(60) \\
\hline IT9210170 & Caldarosa & $\begin{array}{l}\text { Dominant with } Q \text {. } \\
\text { cerris < } 10 \% \text {; } \\
\text { A. alba present. }\end{array}$ & $\begin{array}{l}\text { Siliceus- } \\
\text { arenaceus }\end{array}$ & $1278-1447$ & 43 & 0.828 & 0.591 & 0.286 & 11.8 & 3.37 & H2(43) \\
\hline IT8050053 & Alburni & Pure stand & Carbonate & $980-1500$ & 47 & 0.782 & 0.536 & 0.315 & 11.4 & 3.20 & H1(10); H2(37) \\
\hline IT9210180 & $\begin{array}{l}\text { Madonna } \\
\text { Viggiano }\end{array}$ & Pure stand & $\begin{array}{l}\text { Arenaceus- } \\
\text { carbonate }\end{array}$ & $1250-1727$ & 53 & 0.812 & 0.551 & 0.321 & 12 & 3.34 & H1(36); H2(17) \\
\hline IT8050034 & Maddalena & $\begin{array}{c}\text { Dominant with } \\
\text { Populus tremula, C. } \\
\text { sativa and C. avellana }\end{array}$ & Carbonate & $1000-1310$ & 23 & 0.784 & 0.461 & 0.361 & 8.2 & 3.21 & H1(23) \\
\hline IT9210165 & Alpi & Pure stand & Carbonate & $1030-1615$ & 17 & 0.743 & 0.462 & 0.377 & 6.2 & 2.93 & H1(5); H2(12) \\
\hline
\end{tabular}




\begin{tabular}{|c|c|c|c|c|c|c|c|c|c|c|c|}
\hline \multicolumn{12}{|l|}{ Continued } \\
\hline IT9210185 & La Spina & $\begin{array}{l}\text { Dominant with P. } \\
\text { nigra plus Alnus, } \\
\text { Fraxinus and } \\
\text { termophilus shrubs }\end{array}$ & Carbonate & $930-1395$ & 23 & 0.794 & 0.470 & 0.408 & 8.0 & 3.16 & H1(2); H2(21) \\
\hline \multirow[t]{2}{*}{ IT9110004 } & $\begin{array}{l}\text { Foresta } \\
\text { Umbra }\end{array}$ & $\begin{array}{l}\text { Dominant with } I \text {. } \\
\text { aquifolium and } \\
\text { Hedera elix }\end{array}$ & Carbonate & $600-870$ & 21 & 0.805 & 0.476 & 0.409 & 9.4 & 3.17 & H2 (21) \\
\hline & & Average & & & 34 & 0.784 & 0.564 & 0.279 & 9.7 & - & \\
\hline
\end{tabular}

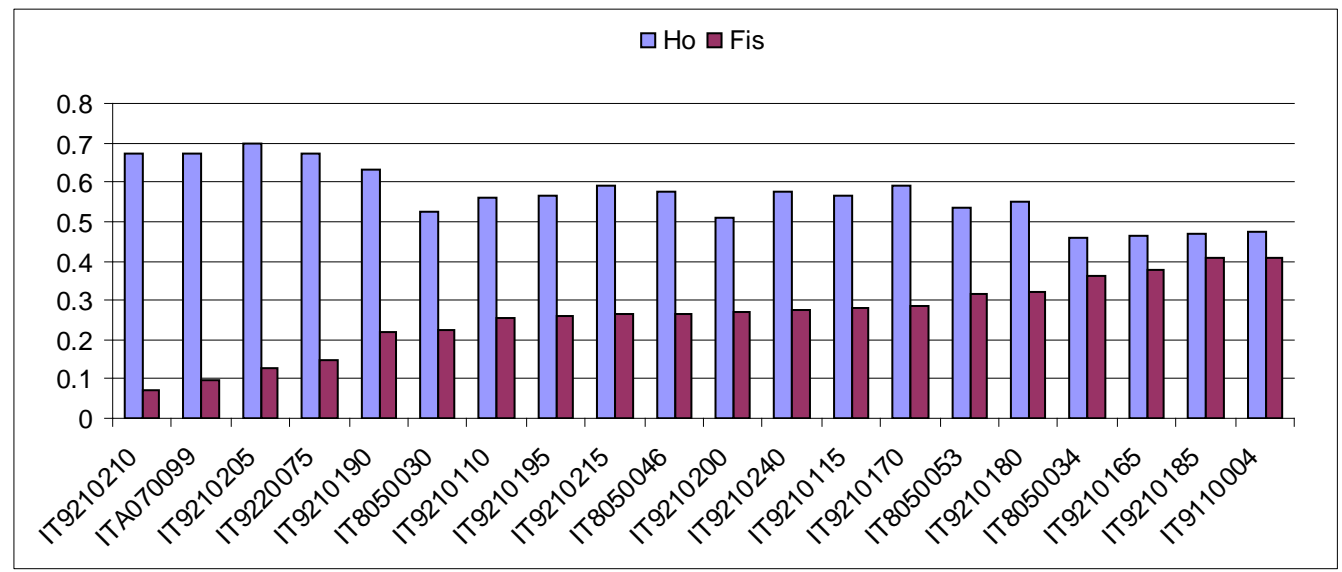

Figure 1. Relationships between Ho and Fis for each sub-population of Fagus sylvatica labeled with its E.U. code.

On the opposite extreme is Foresta Umbra which shows low heterozygosity and the highest Fis. Here, only the most common cytoplasmatic haplotype is present; geographic isolation is evident given that the site is outside the Apennine corridor and $\mathrm{Ne}$ is lower because of maternal common ancestry.

\section{Management Perspective}

Forest genetic diversity is one of the most important resources to be transmitted to the next human generation. Especially beech genetic diversity across the Mediterranean zone should be considered strategic for ecosystems, landscape quality and human services (e.g. mountains as "water towers") [27] [28]. An appropriate in situ conservation of $F$. sylvatica - at least in Natura 2000 sites-by applying the basics of conservation biology rather than usual silviculture (Figure 3) is crucial for habitats and ecosystems [3] [13]. The most hierarchically appropriate conservation action would be the preservation of $\mathrm{Ne}$ being able to generate the fittest next generation from seeds within each beech wood. Shortly, it follows the management guideline based on both $\mathrm{Ho}$ and Fis indicators: where Ho is maximum and Fis minimum (Vulture, Cervati, Paratiello, Volturino e Lago Duglia), it is necessary to avoid impacts by adopting very conservative measures. It is good to consolidate the historical management by maintaining and increasing the actual effective population size. Wind protecting tree layers on the south, south-east faced slopes would be beneficial for beech in reducing the margin effect due to dryness [8] [10]. Such vegetation buffer layer can be realized with broad leaved thermophile species where appropriate (e.g. Quercus cerris, Malus sylvestris, Pyrus pyraster, Acer pseudoplatanus, A. platanoides and A. campestre, Fraxinus angustifolia, F. ornus or Sorbus domestica, S. aucuparia and S. aria). In the remaining sites where it has been monitored a significant deviation from the genetic equilibrium (high Fis) it is necessary to favour gene flow (pollen flow and seed flow). The introduction of genotypes (artificial gene-flow) from the sites with maximum diversity ( $\mathrm{Ho}$ and $\mathrm{A}$ ) can increase site specific genetic diversity $(\mathrm{Ho})$. Site selection for seed sampling can be further improved using as proxies the ecologic factors: pedogenetic substrate, soil type, altimetry, exposition, community structure and composition. Especially on the south and south-east exposed slopes beech cutting and thinning should be avoided. Spring frost and spring-summer dryness are fatal for shoots and coppiced plants. To 


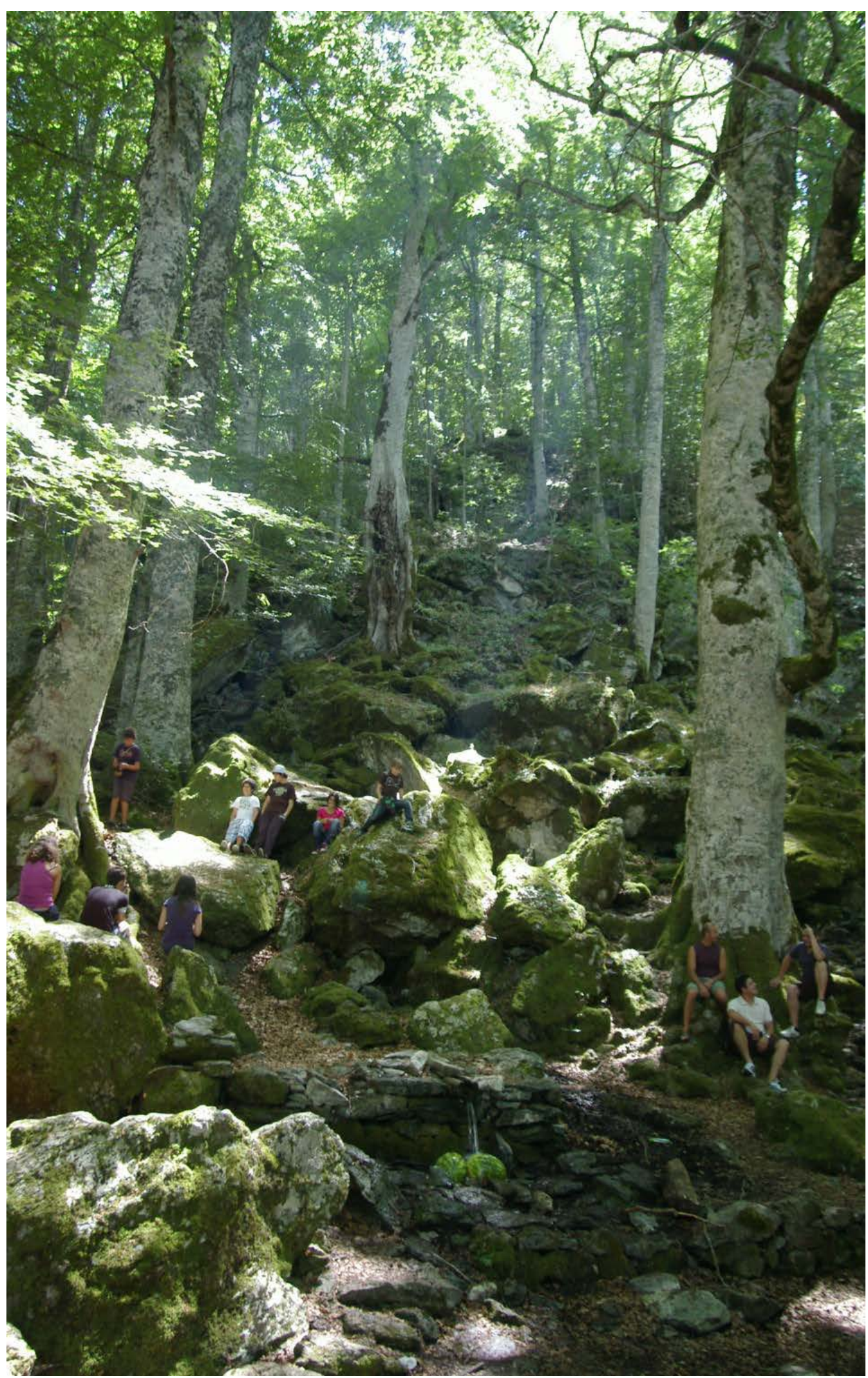

Figure 2. Fagus sylvatica family of effective individuals escaped from the usual thinning/coppicing in Pollino National Park-Italy (site: La Catusa). 


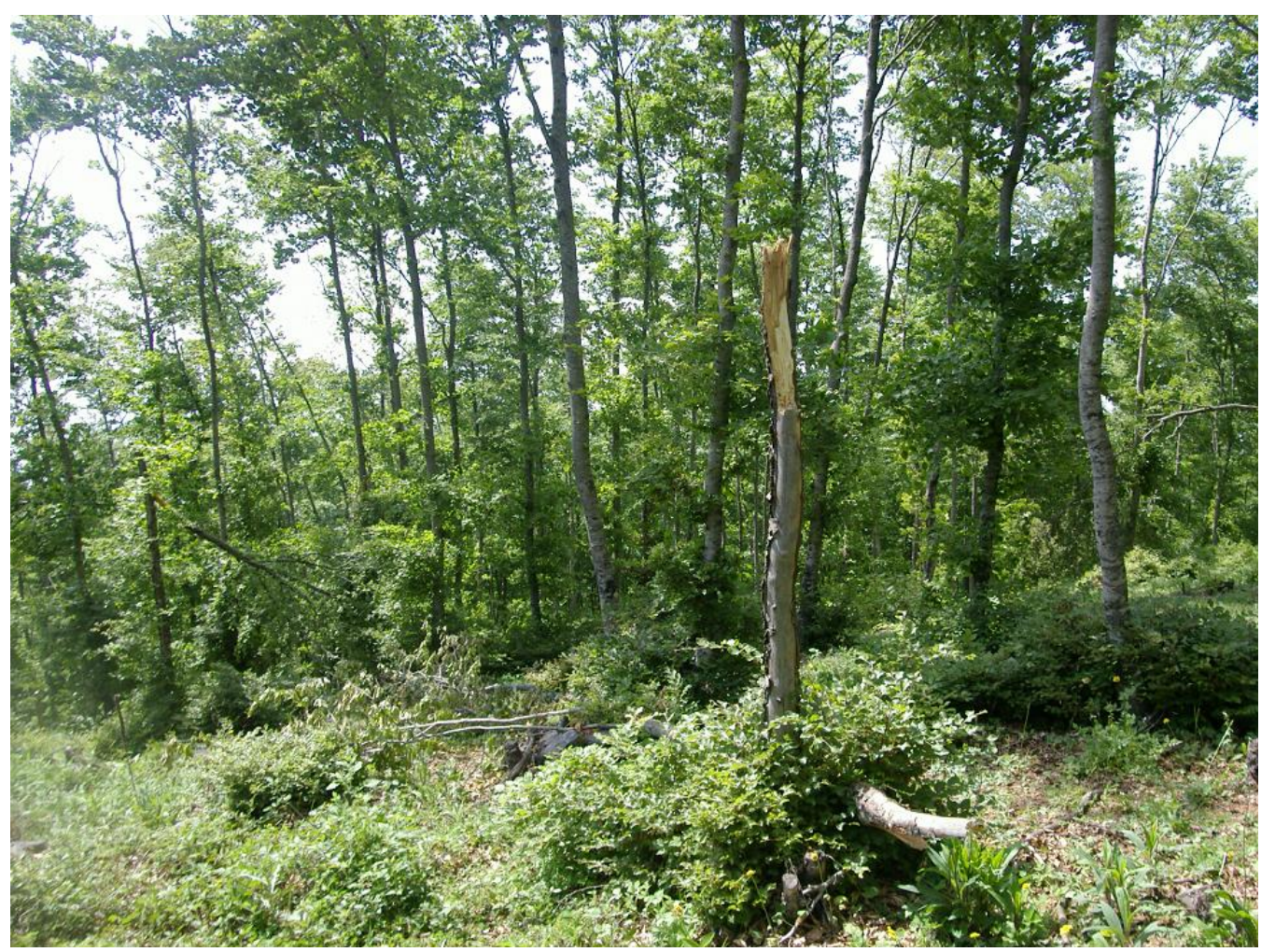

Figure 3. Direct and indirect impacts caused by systematic usual silvicultural methods in Li Foi site (IT9210215).

achieve in situ conservation [29] seeds should be sampled according to specific guidelines [30] [31].

\section{References}

[1] Council Directive 92/43/EEC of 21 May 1992 on the Conservation of Natural Habitats and of Wild Fauna and Flora. Official Journal of the European Union, 1992L0043, 01/01/2007.

[2] Directive 2009/147/EC of the European Parliament and of the Council of 30 November 2009 on the conservation of wild birds. Official Journal of the European Union, L 20/7, 26/1/2010.

[3] Primack, R.B. (2002) Essentials of Conservation Biology. 3rd Edition, Sinauer Associates, Inc., Sunderland.

[4] Moning, C. and Müller, J. (2009) Critical Forest Age thresholds for the Diversity of Lichens, Molluscs and Birds in Beech (Fagus sylvatica L.) Dominated Forests. Ecologic Indicators, 9, 922-932. http://dx.doi.org/10.1016/j.ecolind.2008.11.002

[5] Petit, R.J., Mousadik, A. and Pons, O. (1998) Identifying Populations for Conservation on the Basis of Genetic Markers. Conservation Biology, 12, 844-855. http://dx.doi.org/10.1046/j.1523-1739.1998.96489.x

[6] Myers, N. (1996) Environmental Services of Biodiversity. Proceedings of the National Academy of Sciences of the USA, 93, 2764-2769. http://dx.doi.org/10.1073/pnas.93.7.2764

[7] Darwin, C. (1859) On the Origin of Species by Means of Natural Selection. By Pancaldi, G. 2009. Rizzoli, BUR Eds. (in Italian)

[8] Figliuolo, G. (2011) Landscape Genetics of Fagus sylvatica in One of Its Glacial Refuge Areas. In: Davis, R.E., Ed., Wild Plants: Identification Uses, and Conservation, Nova Science Publishers, Inc., New York, 149-177. https://www.novapublishers.com/catalog/product_info.php?products_id=31892

[9] IPCC, Intergovernmental Panel on Climate Change (2002) Climate Change and Biodiversity, WMO and UNEP.

[10] Jump, A.S., Hunt, J.M. and Panuelas, J. (2006) Rapid Climate Change-Related Growth Decline at the Southern Range Edge of Fagus sylvatica. Global Change Biology, 12, 2163-2174. http://dx.doi.org/10.1111/j.1365-2486.2006.01250.x

[11] Geßler, A., Keitel, C., Kreuzwieser, J., Matyssek, R., Seiler, W. and Rennenberg, H. (2007) Potential Risks for European Beech (Fagus sylvatica L.) in a Changing Climate. Trees, 21, 1-11. http://dx.doi.org/10.1007/s00468-006-0107-x 
[12] Ahuja, M.R. (1991) Giemsa C-Banding in Fagus sylvatica L, Betula pendula Roth and Populus tremula L. Silvae Genetica, 40, 72-75.

[13] Reed, E.T., Schindler, D.E. and Waples, R.S. (2010) Interacting Effects of Phenotypic Plasticity and Evolution on Population Persistence in a Changing Climate. Conservation Biology, 25, 56-63. http://dx.doi.org/10.1111/j.1523-1739.2010.01552.x

[14] Strasburger, E. (2007) Trattato di botanica, Vol 2. Eds. A. Delfino, Roma.

[15] Di Pietro, R., Izko, J. and Blasi, C. (2004) Contribution to the Nomenclatural Knowledge of Fagus sylvatica Woodland of Southern Italy. Plant Biosystems, 138, 27-36. http://dx.doi.org/10.1080/11263500410001684099

[16] Avise, J.C. (1994) Molecular Markers, Natural History and Evolution. Chapman \& Hall, New York. http://dx.doi.org/10.1007/978-1-4615-2381-9

[17] Scalfi, M., Troggio, M., Piovani, P., Leopardi, S., Magnaschi, G., Vendramin, G.G. and Menozzi, P. (2004) A RAPD, AFLP and SSR Linkage Map, and QTL Analysis in European Beech (Fagus selvatica L.). Theoretical and Applied Genetics, 108, 433-441. http://dx.doi.org/10.1007/s00122-003-1583-7

[18] Pastorelli, R., Smulders, M.J.M., Van’t Westende, W.P.C., Vosman, B., Giannini, R., Vettori, C. and Vendramin, G.G. (2003) Characterization of Microsatellite Markers in Fagus sylvatica L. and Fagus orientalis Lipsky. Molecular Ecology Notes, 3, 76-78. http://dx.doi.org/10.1046/j.1471-8286.2003.00355.x

[19] Sebastiani, F., Carnevale, S. and Vendramin, G.G. (2004) A New Set of Mono- and Dinucleotide Chloroplast Microsatellites in Fagaceae. Molecular Ecology Notes, 4, 259-261. http://dx.doi.org/10.1111/j.1471-8286.2004.00635.x

[20] Tanaka, K., Tsumura, Y. and Nakamura, T. (1999) Development and Polymorphism of Microsatellite Markers for Fagus crenata and the Closely Related Species F. japonica. Theoretical and Applied Genetics, 99, 11-15. http://dx.doi.org/10.1007/s001220051203

[21] Weir, B.S. (1996) Genetic Data Analysis II. Sinawer Associates, Inc., Sunderland.

[22] Lewis, P.O. and Zaykin, D. (2001) Genetic Data Analysis: Computer Program for the Analysis of Allelic Data. Version 1.0 (d16c). http://hydrodictyon.eeb.uconn.edu/people/plewis/software.php

[23] Petit, R.J., Mousadik, A. and Pons, O. (1998) Identifying Populations for Conservation on the Basis of Genetic Markers. Conservation Biology, 12, 844-855. http://dx.doi.org/10.1046/j.1523-1739.1998.96489.x

[24] Comps, B., Gomory, D., Letouzey, J., Thiebaut, B. and Petit, R.J. (2001) Diverging Trends between Heterozygosity and Allelic Richness during Postglacial Colonization in the European Beech. Genetics, 157, 389-397.

[25] Leonardi, S. and Menozzi, P. (1995) Genetic Variability of Fagus sylvatica L. in Italy: The Role of Postglacial Recolonization. Heredity, 75, 35-44. http://dx.doi.org/10.1038/hdy.1995.101

[26] Vornam, B., Decarli, N. and Gailing, O. (2004) Spatial Distribution of Genetic Variation in a Natural Beech Stand (Fagus sylvatica L.) Based on Microsatellite Markers. Conservation Genetics, 5, 561-570. http://dx.doi.org/10.1023/B:COGE.0000041025.82917.ac

[27] Myers, N. (1996) Environmental Services of Biodiversity. Proceedings of the National Academy of Sciences of the United States of America, 93, 2764-2769. http://dx.doi.org/10.1073/pnas.93.7.2764

[28] M.E.A. (2005) A Report of the Millennium Ecosystem Assessment. Ecosystems and Human Well-Being. Island Press, Washington DC.

[29] Palmberg-Lerche, C. (1992) Criteria on Choice of Species for Conservation: Woody Plants. In: Kapoor-Vijay, P. and White, J., Eds., Conservation Biology: A Training Manual for Biological Diversity and Genetic Resources, Commonwealth Secretariat, London, 51-60.

[30] Millar, C.I. and Libby, W.J. (1991) Strategies for Conserving Clinal, Ecotypic, and Disjunct Population Diversity in Widespread Species. In: Falk, D.A. and Holsinger, K.E., Eds., Genetics and Conservation of Rare Plants, Oxford University Press, Oxford, 149-170.

[31] Figliuolo, G. (2014) Genetica vegetale per scienze forestali. Arti Grafiche Favia Eds., Bari. 